\title{
Long-term treatment with imatinib results in profound mast cell deficiency in Ph+ chronic myeloid leukemia
}

Sabine Cerny-Reiterer ${ }^{1,2}$, Anja Rabenhorst ${ }^{3}$, Gabriele Stefanzl ${ }^{2}$, Susanne Herndlhofer $^{2}$, Gregor Hoermann ${ }^{4}$, Leonhard Müllauer ${ }^{5}$, Sigrid Baumgartner ${ }^{6}$, Christine Beham-Schmid ${ }^{7}$, Wolfgang R. Sperr ${ }^{1,2}{ }^{2}$ Christine Mannhalter ${ }^{4}$, Heinz Sill ${ }^{8}$, Werner Linkesch ${ }^{8}$, Michel Arock ${ }^{9}$, Karin Hartmann ${ }^{3}$ and Peter Valent ${ }^{1,2}$

${ }^{1}$ Ludwig Boltzmann Cluster Oncology, Medical University of Vienna, Austria

2 Department of Internal Medicine I, Division of Hematology and Hemostaseology, Medical University of Vienna, Austria

${ }^{3}$ Department of Dermatology, University of Cologne, Cologne, Germany

${ }^{4}$ Department of Laboratory Medicine, Medical University of Vienna, Austria

${ }^{5}$ Department of Pathology, Medical University of Vienna, Austria

${ }^{6}$ Department of Pediatrics and Adolescent Medicine, Medical University of Vienna, Austria

${ }^{7}$ Institute of Pathology, Medical University of Graz, Austria

${ }^{8}$ Department of Internal Medicine, Division of Hematology, Medical University of Graz, Austria

9 LBPA CNRS UMR8113, Ecole Normale Supérieure de Cachan, Cachan, France

Correspondence to: Peter Valent, email: peter.valent@meduniwien.ac.at

Keywords: Mast Cells, KIT, Imatinib, Mast Cell Deficiency

Received: October 31, $2014 \quad$ Accepted: December 17, $2014 \quad$ Published: December 26, 2014

This is an open-access article distributed under the terms of the Creative Commons Attribution License, which permits unrestricted use, distribution, and reproduction in any medium, provided the original author and source are credited.

\section{ABSTRACT}

Although mast cells (MC) play an important role in allergic reactions, their physiologic role remains unknown. In mice, several models of MC-deficiency have been developed. However, no comparable human model is available. We examined the in vitro- and in vivo effects of the KIT-targeting drug imatinib on growth and development of human MC. Imatinib was found to inhibit stem cell factor (SCF)induced differentiation of $\mathrm{MC}$ in long-term suspension cultures $\left(\mathrm{IC}_{50}: 0.01 \mu \mathrm{M}\right)$. Correspondingly, long-term treatment of chronic myeloid leukemia (CML) patients with imatinib (400 $\mathrm{mg} / \mathrm{day})$ resulted in a marked decrease in MC. In patients with continuous complete molecular response during therapy, bone marrow MC decreased to less than $5 \%$ of pre-treatment values, and also serum tryptase concentrations decreased significantly (pre-treatment: $32.0 \pm 11.1 \mathrm{ng} / \mathrm{ml}$; post-therapy: $3.4 \pm 1.8$, $\mathrm{p}<\mathbf{0 . 0 1}$ ). Other myeloid lineages, known to develop independently of KIT, were not affected by imatinib-therapy. Imatinib also produced a substantial decrease in MCdevelopment in mice. However, no clinical syndrome attributable to drug-induced MC-deficiency was recorded in our CML patients. Together, imatinib suppresses MC production in vitro and in vivo. However, drug-induced MC depletion is not accompanied by adverse clinical events, suggesting that MC are less relevant to homeostasis in healthy tissues than we assumed so far.

\section{INTRODUCTION}

Mast cells (MC) are bone marrow (BM) stem cell-derived, tissue-fixed, multipotent effector cells of the immune system [1-8]. These cells store a number of vasoactive and immunomodulating substances in their granules and express high-affinity receptors for $\operatorname{IgE}$ [1-10]. During an allergic reaction, $\mathrm{MC}$ release their immunomodulating and vasoactive mediators and thereby contribute to the clinical symptoms of allergy $[1-5,9,10]$. In addition, $\mathrm{MC}$ have been considered to play an important role in other inflammatory reactions, in natural host 
defence, and in tissue homeostasis [1-6].

$\mathrm{MC}$ are a rich source of histamine, various proteases including tryptase and chymase, proteoglycans, and various cytokines such as tumor necrosis factor-alpha [1-5,11-15]. Moreover, MC exhibit a unique profile of profibrinolytic and anti-thrombotic substances, such as tissue-type plasminogen activator (tPA), urokinase receptor, and heparin [16-18]. It has also been described that $\mathrm{MC}$ increase in number and accumulate around thrombosed vessels, and that MC supernatants can dissolve thrombotic clots [16-20]. Finally, it has been described, that india ink-induced fatal thrombosis occurs more frequently in MC-deficient mice than in control animals [21]. Other studies have shown that MCdeficient mice are more susceptible to fatal bacterial infections compared to control animals [22,23]. All these observations suggest that MC may fulfil important functions in i) the immune system and ii) in the vascular repair system under pathologic conditions. In addition, $\mathrm{MC}$ have been considered to play a role in normal tissue homeostasis. However, the exact role of MC in normal healthy (physiologic) tissues has not been described yet. Whereas several models of MC deficiency are available in the murine system [1,21-25], no comparable model of human $\mathrm{MC}$ deficiency is available.

A number of previous studies have shown that the ligand of the KIT tyrosine kinase receptor, stem cell factor (SCF), promotes the in vitro growth and development of MC [26-29]. In line with this concept, MC and MC progenitors express KIT throughout their development [28-30]. Moreover, it is well accepted that SCF-deficient mice and KIT-deficient mice exhibit profound MC deficiency $[24,25]$. SCF-dependent development of MC from their immature progenitor cells is a long-lasting process that takes several months [26-29]. In addition, mature $\mathrm{MC}$ in various organs are considered to be longlived cells that can persist in local tissue sites for several years [31].

During the past decade, the tyrosine kinase inhibitor (TKI) imatinib has been successfully used for the treatment of patients with BCR/ABL1+ chronic myeloid leukemia (CML) and for the treatment of FIP1L1/ PDGFRA+ chronic eosinophilic leukemia (CEL) [32-36]. In fact, imatinib is a potent inhibitor of BCR/ABL1 and FIP1L1/PDGFRA. In many patients with CML, long-term disease-free survival and major (MMR) or even complete molecular responses (CMR) are obtained [32-35]. In addition, imatinib is a highly potent inhibitor of the KIT tyrosine kinase [37]. However, the effect of imatinib on KIT-dependent cells, especially tissue MC, remains at present unknown. In the current study, we asked whether long-term treatment of CML patients with imatinib is associated with $\mathrm{MC}$ deficiency.

\section{RESULTS}

\section{Imatinib inhibits SCF-induced differentiation of human MC in long-term culture}

It is generally appreciated that SCF promotes the development and differentiation of human MC [1-3,2628]. In the present study, we were able to confirm the MC growth-stimulating effect of SCF on CB-derived $\mathrm{MC}$ precursor cells in long-term suspension cultures. In particular, as assessed by Wright-Giemsa staining, substantial numbers of $\mathrm{MC}$ were detectable in SCFsupplemented cultures on day 28 , whereas in cultures maintained in control medium (without SCF), no MC were detected (not shown). In addition, cellular histamineand tryptase levels were measured in CB precursor cells cultured in the presence of SCF. In these cultures, imatinib was found to inhibit SCF-dependent differentiation of $\mathrm{MC}$ in a dose-dependent manner (Figure 1). The growthinhibitory effects of imatinib on MC development were demonstrable by morphological examination (Figure 1A) as well as by measuring total histamine and total tryptase levels in cultured cells (Figure 1B). In addition, imatinib was found to inhibit SCF-induced expression of tryptase mRNA and KIT mRNA in long-term suspension cultures (Figure 1C). Together, these data show that imatinib exerts profound inhibitory effects on SCF-dependent development and differentiation of human $\mathrm{MC}$ in vitro.

\section{Long-term treatment of CML patients with imatinib is associated with a substantial decrease in the numbers of $\mathrm{BM} \mathrm{MC}$}

The numbers of tryptase + cells and the numbers of $\mathrm{KIT}+$ cells in the BM of newly diagnosed patients with CML exceeded the numbers of tryptase + and KIT + cells detected in the normal BM (Figure 2A and 2B) suggesting an expansion of clonal tryptase + cells. After efficacious long-term treatment with imatinib, defined by MMR (or CMR) for at least 24 months, the numbers of tryptase+ cells and the numbers of KIT+ cells decreased significantly $(\mathrm{p}<0.001)$ compared to pre-treatment values (Figure $2 \mathrm{~A}$ and $2 \mathrm{~B}$ ). In addition, we found that the numbers of tryptase + cells and $\mathrm{KIT}+$ cells in the BM of our long-termtreated patients were even lower when compared to the numbers of tryptase + cells or KIT + cells $(\mathrm{MC})$ detectable in the normal BM $(\mathrm{p}<0.01)$ (Figure 2A and 2B). The MCdepleting effect of imatinib was confirmed by Giemsastaining (Figure 2C). Figure 2D shows examples of immunohistochemical stains performed with antibodies against tryptase and KIT in BM sections obtained from patients with CML before and after therapy with imatinib. We also confirmed that long-term treatment with imatinib results in a complete depletion of clonal cells in the BM. 
In fact, in all MMR patients tested, BCR/ABL1 mRNA levels in $\mathrm{BM}$ mononuclear cells were $<0.1 \%$ by qPCR, similar to peripheral blood BCR/ABL levels (not shown). Since MC development is a long-lasting process and MC may persist in normal tissues for several years [31] we also examined BM sections of patients treated with imatinib for less than 1 year. In this cohort of patients $(n=6)$ the numbers of tryptase + cells and KIT + cells (MC) also decreased slightly compared to pre-treatment values, but the decrease was not significant, and the concentrations of tryptase+ cells and KIT+ cells in the BM were comparable to that found in the normal BM (Supplemental Figure S1).

\section{Tryptase mRNA- and KIT mRNA levels during treatment with imatinib}

In order to confirm imatinib-induced $\mathrm{MC}$ deficiency in our CML patients, we examined MNC derived from aspirated BM samples by qPCR using primers specific for mast cell tryptase and KIT. As visible in Figure 3, tryptase mRNA levels and KIT mRNA levels decreased significantly during successful long-term treatment with imatinib in all patients examined. In these patients, tryptase mRNA levels and KIT mRNA levels were found to be even lower when compared to that found in normal BM cells $(\mathrm{p}<0.01)$ (Figure 3).
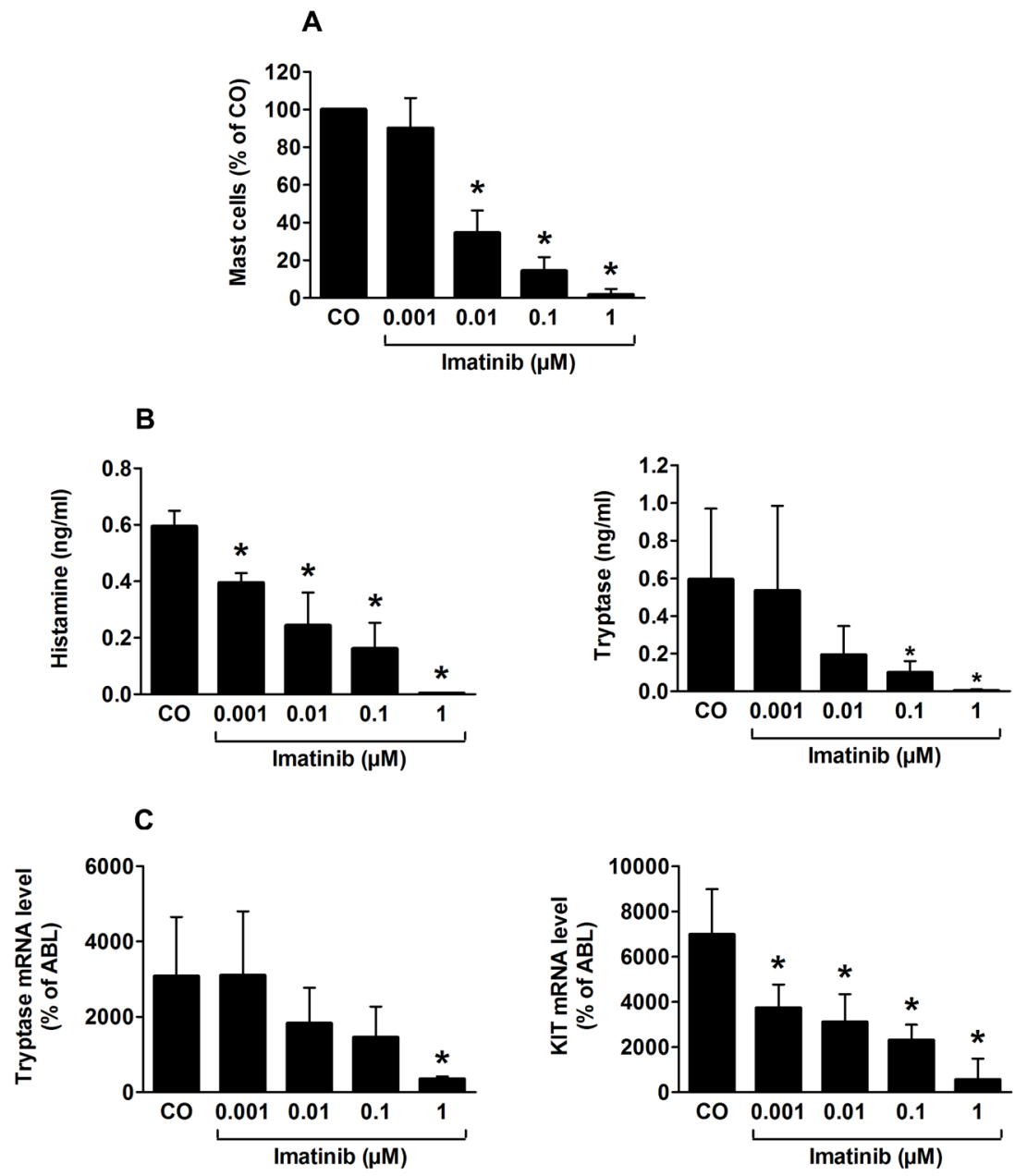

Figure 1: Imatinib inhibits SCF-induced in vitro differentiation of human mast cells. A: Isolated cord blood MNC (1x10\% $\mathrm{ml}$ ) were cultured in 24-well plates in RPMI medium containing 10\% FCS, IL-6 and SCF (each $100 \mathrm{ng} / \mathrm{ml}$ ) in the presence or absence (CO) of various concentrations of imatinib $(0.001-1 \mu \mathrm{M})$ at $37^{\circ} \mathrm{C}$ for 28 days. Thereafter, the total numbers of mast cells (MC) per well were determined by measuring total cell counts and the percentage of $\mathrm{MC}$ on Giemsa-stained slides. Cells were counted using an Olympus AX-1 microscope equipped with a 100x/1.35 UPlan-Apo objective lens. Results represent the mean \pm S.D. from 3 independent experiments. Asterisk: $\mathrm{p}<0.05$. B: Total histamine levels per well assessed by RIA (left panel) and total tryptase levels assessed by FEIA (right panel) were determined on day 28. Results represent the mean \pm S.D. from 3 independent experiments. Asterisk: $p<0.05$. C: Expression of tryptase mRNA levels (left panel) and KIT (CD117) mRNA levels (right panel) determined by qPCR on day 28. Results show tryptase and KIT mRNA expression levels as percent of $A B L m R N A$ levels, and represent the mean \pm S.D. from 3 independent experiments. Asterisk: $p<0.05$. 

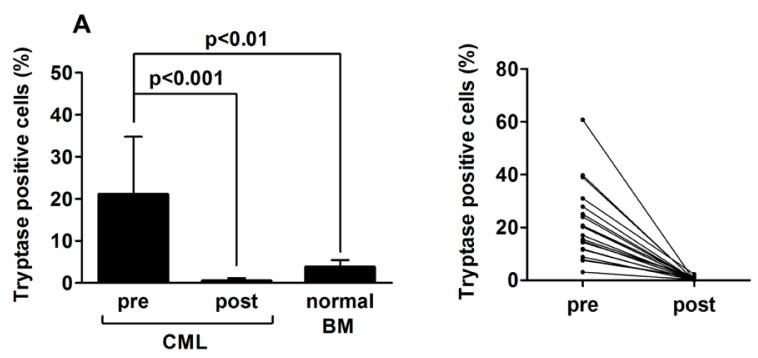

B
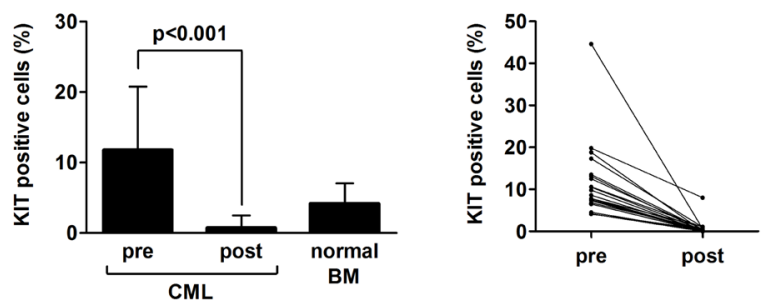

C
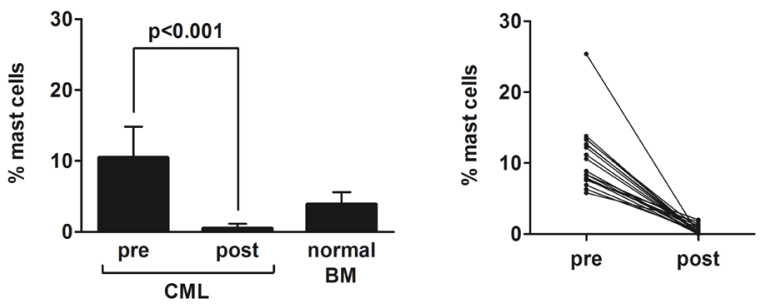

D
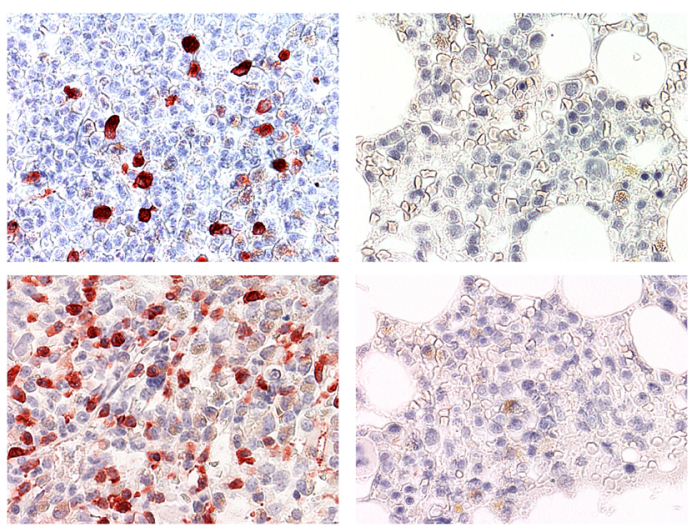

Figure 2: Imatinib induces mast cell deficiency in the bone marrow of patients with CML. Bone marrow (BM) biopsy material was obtained from patients with CML $(n=23)$ at diagnosis and at the time of major or complete molecular response and at least 2 years on therapy with imatinib (400 mg/day). In addition, control BM section from 5 patients were examined. Serial sections were prepared from paraffin-embedded BM specimens and stained with antibodies against tryptase (A) and against KIT (B) by indirect immunohistochemistry as well as by Giemsa-staining (C). The percentages of tryptase + mast cells (MC) and KIT+ MC relative to all nucleated BM cells (500 cells counted), was determined using an Olympus AX-1 microscope equipped with 100x/1.35 UPlan-Apo objective lens. Results in the left panels represent the mean \pm S.D. (percent-values) from all donors before and after therapy, and a comparison to normal control BM samples $(\mathrm{n}=5)$. The right panels show the percentages of tryptase+ MC and KIT+ MC in each individual patient before and after therapy. In C, the numbers of MC was determined by Giemsa-staining (percent of all nucleated BM cells) using an Olympus AX-1 microscope. Results in the left panel represent the mean \pm S.D. from all donors before and after therapy, and a comparison to normal control BM samples $(\mathrm{n}=5)$. The right panel shows the percentages of MC in each individual patient. D: Examples of BM sections stained for tryptase (upper panels) and KIT (lower panels) at diagnosis (upper and lower left panels) and at the time of re-investigation (upper and lower right panels) by indirect immunohistochemistry. Cells were analyzed using an Olympus AX-1 microscope equipped with 40x/0.85 UPlan-Apo objective lens. Images were taken using an Olympus DP21 camera and adjusted by Adobe Photoshop CS2 software Version 9.0 (Adobe Systems). 
Table 1: Patients' characteristics at diagnosis

\begin{tabular}{|c|c|c|c|c|c|c|c|c|c|c|c|c|c|}
\hline Pat.No. & Gender & Age $(y)$ & Phase & $\begin{array}{l}\text { WBC } \\
(G / L)\end{array}$ & $\begin{array}{c}\text { Hb } \\
(G / d L)\end{array}$ & $\begin{array}{c}\text { Plt } \\
(\mathrm{G} / \mathrm{L})\end{array}$ & $\begin{array}{c}\text { PB } \\
\text { Basophils } \\
(\%)\end{array}$ & $\begin{array}{c}\text { PB } \\
\text { Blasts } \\
(\%)\end{array}$ & $\begin{array}{c}\text { PB } \\
\text { Eosinophils } \\
(\%)\end{array}$ & $\begin{array}{c}\text { BM } \\
\text { Basophils } \\
(\%)\end{array}$ & $\begin{array}{c}\text { BM } \\
\text { Blasts } \\
(\%)\end{array}$ & Cytogenetic & $\begin{array}{c}\text { BCR/ABL1 } \\
\text { PB } \\
(\%)\end{array}$ \\
\hline 1 & $\mathrm{~m}$ & 29 & $\mathrm{CP}$ & 375.3 & 10.6 & 193 & 2 & 2 & 1 & 2 & 2 & $46, \mathrm{XY}, \mathrm{t}(9 ; 22)(\mathrm{q} 34 ; \mathrm{q} 11)$ & 63.08 \\
\hline 2 & $\mathrm{f}$ & 58 & $\mathrm{CP}$ & 70.8 & 10.8 & 1722 & 11 & 3 & 2 & 8 & 7 & $46, \mathrm{XX}, \mathrm{t}(9 ; 22)(\mathrm{q} 34 ; \mathrm{q} 11)$ & 53.00 \\
\hline 3 & f & 36 & $\mathrm{CP}$ & 193.8 & 11.5 & 222 & 4 & 1 & 2 & $<1$ & 2 & $46, \mathrm{XX}, \mathrm{t}(9 ; 10 ; 22)(\mathrm{q} 34 ; \mathrm{q} 22 ; \mathrm{q} 11)$ & 100.00 \\
\hline 4 & $\mathrm{~m}$ & 37 & $\mathrm{CP}$ & 381.0 & 9.7 & 275 & 5 & 3 & 4 & 4 & 3 & $46, \mathrm{XY}, \mathrm{t}(9 ; 22)(\mathrm{q} 34 ; \mathrm{q} 11)$ & 18.44 \\
\hline 5 & $\mathrm{~m}$ & 60 & $\mathrm{CP}$ & 171.0 & 12.1 & 305 & 2 & 1 & 0 & 2 & $<1$ & $46, X Y, t(9 ; 22)(\mathrm{q} 34 ; \mathrm{q} 11)$ & pos. qualitat \\
\hline 6 & $\mathrm{~m}$ & 64 & $\mathrm{CP}$ & 342.0 & 8.9 & 478 & 7 & 1 & 2 & 6 & 3 & $46, X Y, t(9 ; 22)(\mathrm{q} 34 ; \mathrm{q} 11)$ & 14.30 \\
\hline 7 & $\mathrm{f}$ & 63 & $\mathrm{CP}$ & 43.5 & 11.7 & 265 & 19 & 1 & 3 & 10 & 4 & $46, \mathrm{XX}, \mathrm{t}(9 ; 22)(\mathrm{q} 34 ; \mathrm{q} 11)$ & 7.50 \\
\hline 8 & $\mathrm{~m}$ & 47 & $\mathrm{CP}$ & 55.7 & 13.9 & 250 & 1 & 1 & 0 & 1 & 3 & $46, X Y, t(9 ; 22)(\mathrm{q} 34 ; \mathrm{q} 11)$ & 34.40 \\
\hline 9 & $\mathrm{f}$ & 42 & $\mathrm{CP}$ & 61.2 & 13.5 & 319 & 3 & 0 & 1 & $<1$ & $<1$ & $46, \mathrm{XX}, \mathrm{t}(9 ; 22)(\mathrm{q} 34 ; \mathrm{q} 11)$ & 61.60 \\
\hline 10 & $\mathrm{~m}$ & 60 & $\mathrm{CP}$ & 29.9 & 15.7 & 252 & 6 & 0 & 3 & 2 & 1 & $46, X Y, t(9 ; 22)(\mathrm{q} 34 ; \mathrm{q} 11)$ & 62.70 \\
\hline 11 & $\mathrm{~m}$ & 37 & $\mathrm{BP}$ & 104.3 & 11.4 & 137 & 6 & 17 & 10 & 10 & 19 & $46, \mathrm{XY}, \mathrm{t}(9 ; 22)(\mathrm{q} 34 ; \mathrm{q} 11)$ & 76.00 \\
\hline 12 & $\mathrm{~m}$ & 55 & $\mathrm{CP}$ & 46.7 & 11.9 & 336 & 9 & 1 & 1 & $<1$ & $<1$ & $46, \mathrm{XY}, \mathrm{t}(9 ; 22)(\mathrm{q} 34 ; \mathrm{q} 11)$ & 63.00 \\
\hline 13 & $\mathrm{f}$ & 57 & $\mathrm{CP}$ & 175.2 & 9.8 & 216 & 4 & 4 & 7 & 3 & 2 & $46, \mathrm{XX}, \mathrm{t}(9 ; 22)(\mathrm{q} 34 ; \mathrm{q} 11)$ & 82.60 \\
\hline 14 & $\mathrm{f}$ & 63 & $\mathrm{CP}$ & 49.1 & 13.0 & 385 & 2 & 0 & 1 & 0 & 1 & $46, \mathrm{XX}, \mathrm{t}(8 ; 9 ; 22)(\mathrm{q} 13 ; \mathrm{q} 34 ; \mathrm{q} 11)$ & pos. qualitat \\
\hline 15 & $\mathrm{f}$ & 59 & $\mathrm{CP}$ & 69.1 & 12.7 & 297 & 2 & 0 & 4 & 0 & 1 & $46, \mathrm{XX}, \mathrm{t}(9 ; 22)(\mathrm{q} 34 ; \mathrm{q} 11)$ & pos. qualitat \\
\hline 16 & $\mathrm{~m}$ & 40 & $\mathrm{CP}$ & 86.2 & 13.9 & 134 & 4 & 0 & 1 & n.d. & n.d. & $46, X Y, \mathrm{t}(9 ; 22)(\mathrm{q} 34 ; \mathrm{q} 11)$ & 19.20 \\
\hline 17 & $\mathrm{~m}$ & 58 & $\mathrm{CP}$ & 170.0 & 9.6 & 506 & 1 & 2 & 4 & 2 & 0 & $46, \mathrm{XY}, \mathrm{t}(9 ; 22)(\mathrm{q} 34 ; \mathrm{q} 11)$ & 49.00 \\
\hline 18 & $\mathrm{~m}$ & 55 & $\mathrm{CP}$ & 142.0 & 11.9 & 465 & 7 & 7 & 6 & 8 & 5 & $46, \mathrm{XY}, \mathrm{t}(9 ; 17 ; 22)(\mathrm{q} 34 ; \mathrm{q} 25 ; \mathrm{q} 11)$ & 15.80 \\
\hline 19 & $\mathrm{~m}$ & 58 & $\mathrm{CP}$ & 183.0 & 8.5 & 397 & 15 & 10 & 6 & 7 & 4 & $46, \mathrm{XY}, \mathrm{t}(9 ; 22)(\mathrm{q} 34 ; \mathrm{q} 11)$ & pos. qualitat \\
\hline 20 & $\mathrm{~m}$ & 42 & $\mathrm{CP}$ & 147.5 & 10.2 & 528 & 3 & 0 & 3 & $<1$ & 1 & $\begin{array}{c}46, \mathrm{XY}, \mathrm{t}(9 ; 22)(\mathrm{q} 34 ; \mathrm{q} 11), \operatorname{del}(11) \\
(\mathrm{q} 23)\end{array}$ & 88.10 \\
\hline 21 & $\mathrm{f}$ & 36 & $\mathrm{CP}$ & 96.1 & 14.3 & 800 & 11 & 1 & 4 & 2 & 2 & $46, \mathrm{XX}, \mathrm{t}(9 ; 22)(\mathrm{q} 34 ; \mathrm{q} 11)$ & 30.00 \\
\hline 22 & $\mathrm{f}$ & 44 & $\mathrm{CP}$ & 103.4 & 11.8 & 569 & 3 & 1 & 2 & 1 & 1 & $46, \mathrm{XX}, \mathrm{t}(9 ; 22)(\mathrm{q} 34 ; \mathrm{q} 11)$ & 13.00 \\
\hline 23 & $\mathrm{~m}$ & 50 & $\mathrm{CP}$ & 33.6 & 11.4 & 351 & 1 & 0 & 0 & $<1$ & $2-3$ & $46, X Y, t(9 ; 22)(\mathrm{q} 34 ; \mathrm{q} 11)$ & 36.50 \\
\hline 24 & $\mathrm{~m}$ & 43 & $\mathrm{BP}$ & 67.1 & 13.7 & 1460 & 1 & 2 & 3 & 0 & 18 & n.d. & 13.10 \\
\hline 25 & $\mathrm{f}$ & 57 & $\mathrm{CP}$ & 124 & 13.6 & 549 & 0 & 1 & 0 & 0 & 0 & n.d. & 13.40 \\
\hline 26 & $\mathrm{f}$ & 65 & $\mathrm{BP}$ & 1.65 & 10.5 & 48 & 1 & 0 & 5.5 & 1 & 35 & n.d. & 19.00 \\
\hline 27 & $\mathrm{f}$ & 61 & $\mathrm{CP}$ & 15.5 & 13 & 870 & 5 & 0 & 3 & 0 & 0 & n.d. & 15.30 \\
\hline 28 & $\mathrm{~m}$ & 59 & $\mathrm{CP}$ & 98.6 & 13.3 & 338 & 4 & 1 & 2 & 0 & 0 & n.d. & 37.20 \\
\hline 29 & $\mathrm{~m}$ & 68 & $\mathrm{CP}$ & 20.2 & 15.2 & 417 & 10 & 0 & 1 & 0 & 2 & n.d. & 20.10 \\
\hline
\end{tabular}

Abbreviations: y, year; WBC, white blood count; $\mathrm{Hb}$, hemoglobin; Plt, platelets; $\mathrm{BM}$, bone marrow; PB, peripheral blood; m, male; f, female; $\mathrm{CP}$, chronic phase; $\mathrm{BP}$, blast phase; pos. qualitat., BCR/ABL1+ by qualitative PCR; n.d., not determined.

\section{Successful long-term treatment with imatinib induces a systemic decrease in MC}

In a next step, we asked whether the effect of imatinib on MC is a systemic effect. In order to address this question, we measured serum tryptase levels before and after treatment with imatinib in a subset of our patients, and compared post-treatment levels to pretreatment levels and to tryptase levels in healthy controls. As visible in Figure 4, tryptase levels at diagnosis were found to be higher compared to tryptase levels in healthy controls $(\mathrm{p}<0.01)$. After treatment with imatinib, serum tryptase levels decreased significantly in all patients when compared to pre-treatment levels $(\mathrm{p}<0.001)$ or to tryptase levels in controls $(p<0.05)$ (Figure 4). In several cases, tryptase decreased to very low or even undetectable levels (not shown). To exclude that the low serum tryptase level resulted from deactivation of $\mathrm{MC}$ rather than depletion of MC, we also performed activation experiments. In these experiments, we found that imatinib neither blocks IgE-dependent nor SCF-mediated release of histamine in $\mathrm{CB}$ precursor-derived $\mathrm{MC}$ or human lung $\mathrm{MC}$ (not shown). Together, these data provide evidence that longterm treatment with imatinib results in a substantial systemic decrease in MC numbers. Finally, we examined the influence of long-term imatinib therapy on growth and differentiation of other blood cells. However, no significant changes in white blood cell numbers were found when comparing long-term treated CML patients with normal blood counts (Table 3). Finally, we were unable to record any adverse events possibly related to MC-depletion in our CML patients treated with imatinib, even when MC numbers had decreased to very low levels. In particular, no increased frequency in thromboembolic events, severe bacterial or fungal infections or bleedings, were recorded (Table 4). We were also unable to detect an increased rate of secondary cancer or leukemias in our imatinib-treated patients. The most frequent adverse event was mild to moderate (facial/lid) edema, confirming previous observations [32-34].

\section{Treatment with imatinib induces a marked decrease in MC numbers in mice}

To confirm the effect of imatinib on MC numbers in vivo in mice, two different mouse strains were employed. Intraperitoneal injection of imatinib $(60 \mathrm{mg} / \mathrm{kg} / \mathrm{day})$ in C57BL/6J mice for 42 days resulted in a time-dependent decrease in $\mathrm{MC}$ in various organ-sites, including the back-skin, ear-skin, and the gastrointestinal tract, i.e. gastric mucosa (Figure 5A-C). MC numbers in the backskin decreased from $36.7 \pm 10.1$ per high power field (control mice on day 42) to $15.7 \pm 4.6$ per high power field in imatinib-treated animals on day $42(\mathrm{p}<0.05)$, and a similar decrease was observed in the ear-skin and in the intestinal mucosa of imatinib-treated C57BL/6J 
Table 2: Patient's characteristics at the time of re-investigation (patients in MMR or CMR after 2 to 10 years)

\begin{tabular}{|c|c|c|c|c|c|c|c|c|c|c|c|c|}
\hline Pat.No. & Gender & $\begin{array}{l}\text { Age } \\
\text { (y) }\end{array}$ & $\begin{array}{l}\text { Time(y) } \\
\text { after } \\
\text { Diagnosis }\end{array}$ & $\begin{array}{l}\text { WBC } \\
(\mathrm{G} / \mathrm{L})\end{array}$ & $\begin{array}{l}\mathrm{Hb} \\
(\mathrm{G} / \mathrm{dL})\end{array}$ & $\begin{array}{l}\text { Plt } \\
(\mathrm{G} / \mathrm{L})\end{array}$ & $\begin{array}{l}\text { PB } \\
\text { Basophils } \\
(\%)\end{array}$ & $\begin{array}{l}\text { PB } \\
\text { Blasts } \\
(\%)\end{array}$ & $\begin{array}{l}\text { BM } \\
\text { Basophils } \\
(\%)\end{array}$ & $\begin{array}{l}\text { BM } \\
\text { Blasts (\%) }\end{array}$ & Cytogenetic & $\begin{array}{l}\text { BCR/ } \\
\text { ABL1 } \\
\text { PB } \\
(\%) \\
\end{array}$ \\
\hline 1 & $\mathrm{~m}$ & 31 & 2 & 2.93 & 14.3 & 140 & 0 & 0 & 0 & 0 & $46, X Y$ & 0.061 \\
\hline 2 & $\mathrm{f}$ & 70 & 11 & 4.24 & 11.2 & 68 & 0 & 0 & 1 & 1 & $46, X X$ & 0.020 \\
\hline 3 & $\mathrm{f}$ & 40 & 3 & 2.79 & 12.6 & 122 & 0 & 0 & $<0,5$ & 1 & n.d. & 0.009 \\
\hline 4 & $\mathrm{~m}$ & 46 & 8 & 6.54 & 14.2 & 204 & 1 & 0 & $<1$ & 2 & $46, X Y$ & 0.092 \\
\hline 5 & $\mathrm{~m}$ & 67 & 7 & 5.85 & 12.6 & 157 & 1 & 0 & $<1$ & 1 & $46, X Y$ & 0.000 \\
\hline 6 & $\mathrm{~m}$ & 71 & 7 & 4.13 & 12.0 & 134 & 0 & 0 & $<1$ & 1 & $46, X Y$ & 0.031 \\
\hline 7 & $\mathrm{f}$ & 71 & 8 & 4.76 & 12.2 & 232 & 0 & 0 & $<1$ & 1 & $46, X X$ & 0.000 \\
\hline 8 & $\mathrm{~m}$ & 50 & 7 & 4.94 & 13.7 & 176 & 1 & 0 & $<1$ & 1 & $46, X Y$ & 0.018 \\
\hline 9 & $f$ & 47 & 5 & 4.89 & 11.3 & 194 & 1 & 0 & $<1$ & 1 & $46, \mathrm{XX}$ & 0.013 \\
\hline 10 & $\mathrm{~m}$ & 63 & 3 & 5.37 & 14.8 & 179 & 0 & 0 & $<1$ & 1 & 46,XY & 0.002 \\
\hline 11 & $\mathrm{~m}$ & 43 & 5 & 4.65 & 11.7 & 147 & 1 & 0 & $<1$ & 1 & $46, X Y$ & 0.013 \\
\hline 12 & $\mathrm{~m}$ & 60 & 5 & 4.77 & 13.0 & 254 & 1 & 0 & $<1$ & 1 & $46, X Y$ & 0.000 \\
\hline 13 & $\mathrm{f}$ & 63 & 6 & 4.63 & 12.6 & 206 & 0 & 0 & $<1$ & 1 & $46, \mathrm{XX}$ & 0.025 \\
\hline 14 & $\mathrm{f}$ & 74 & 10 & 5.84 & 11.4 & 256 & 1 & 0 & $<1$ & 1 & $46, X X$ & 0.055 \\
\hline 15 & $\mathrm{f}$ & 69 & 10 & 4.23 & 10.7 & 225 & 0 & 0 & $<1$ & 1 & $46, X X$ & 0.005 \\
\hline 16 & $\mathrm{~m}$ & 48 & 7 & 7.29 & 15.6 & 177 & 2 & 0 & $<1$ & 1 & $46, X Y$ & 0.007 \\
\hline 17 & $\mathrm{~m}$ & 71 & 12 & 4.58 & 15.1 & 108 & 0 & 0 & $<1$ & 2 & n.d. & 0.000 \\
\hline 18 & $\mathrm{~m}$ & 64 & 9 & 5.38 & 12.6 & 139 & 0 & 0 & $<1$ & 1 & 46,XY & 0.011 \\
\hline 19 & $\mathrm{~m}$ & 69 & 11 & 6.22 & 12.8 & 120 & 0 & 0 & $<1$ & $<1$ & 46,XY & 0.013 \\
\hline 20 & $\mathrm{~m}$ & 48 & 6 & 5.73 & 12.5 & 302 & 0 & 0 & $<1$ & 1 & 46,XY & 0.016 \\
\hline 21 & $f$ & 47 & 11 & 5.62 & 12.5 & 230 & 0 & 0 & $<1$ & 1 & $46, \mathrm{XX}$ & 0.000 \\
\hline 22 & $\mathrm{f}$ & 48 & 4 & 2.94 & 11.8 & 238 & 2 & 0 & 1 & $<1$ & $46, \mathrm{XX}$ & 0.000 \\
\hline 23 & $\mathrm{~m}$ & 52 & 2 & 5.39 & 14.1 & 173 & 0 & 0 & $<1$ & 2 & $46, X Y$ & 0.000 \\
\hline 24 & $\mathrm{~m}$ & 44 & 1 & 3.01 & 9.4 & 34 & 1 & 0 & 0 & 0 & n.d. & 0.000 \\
\hline 25 & $\mathrm{f}$ & 58 & 1 & 7.1 & 13.4 & 261 & 0 & 0 & 0 & 0 & n.d. & 0.403 \\
\hline 26 & $\mathrm{f}$ & 65 & 0.5 & 4.19 & 13.1 & 50 & 0 & 0 & 2.1 & 0 & n.d. & 0.023 \\
\hline 27 & $\mathrm{f}$ & 62 & 1 & 8.34 & 12.4 & 353 & 1 & 0 & 3 & 0 & n.d. & 0.140 \\
\hline 28 & $\mathrm{~m}$ & 59 & 0.4 & 3.6 & 13 & 77 & 0 & 0 & 1 & 0 & n.d. & 0.860 \\
\hline 29 & $\mathrm{~m}$ & 69 & 1 & 6.6 & 14.3 & 325 & 0 & 0 & 5 & 0 & n.d. & 0.577 \\
\hline
\end{tabular}

Abbreviations: y, year; WBC, white blood count; Hb, hemoglobin; Plt, platelets; BM, bone marrow; PB, peripheral blood; m, male; f, female, n.d., not determined

Table 3: Differential counts at the time of at least major molecular response (MMR)

\begin{tabular}{|c|c|c|c|c|}
\hline & $\begin{array}{c}\text { absolute } \\
\text { numbers }(\mathrm{G} / \mathrm{L})\end{array}$ & $\begin{array}{c}\text { reference } \\
\text { values }(\mathrm{G} / \mathrm{L})\end{array}$ & $\begin{array}{c}\text { relative } \\
\text { numbers }(\%)\end{array}$ & $\begin{array}{c}\text { reference } \\
\text { values }(\%)\end{array}$ \\
\hline Neutrophils & $2.87 \pm 0.84$ & $2.0-7.5$ & $57.61 \pm 9.40$ & $50-75$ \\
\hline Lymphocytes & $1.51 \pm 0.50$ & $1.0-4.0$ & $31.13 \pm 8.85$ & $25-40$ \\
\hline Monocytes & $0.36 \pm 0.15$ & $0.0-1.2$ & $7.43 \pm 2.74$ & $0-12$ \\
\hline Eosinophils & $0.17 \pm 0.17$ & $0.0-0.4$ & $3.30 \pm 2.98$ & $0-4$ \\
\hline Basophils & $0.03 \pm 0.04$ & $0.0-0.1$ & $0.47 \pm 0.67$ & $0.0-1.0$ \\
\hline
\end{tabular}

Leukocyte counts were determine in all CML patients $(n=23)$ before the start of therapy with imatinib and during therapy at the time of (at least) MMR. Differential counts were examined on Wright-Giemsastained blood smears. 
Table 4: Adverse events possibly related to mast cell deficiency or mast cell activation

\begin{tabular}{|c|c|c|c|c|c|c|}
\hline Pat No & $\begin{array}{l}\text { Throboembolic } \\
\text { Events }\end{array}$ & $\begin{array}{c}\text { Bacterial or } \\
\text { Fungal Infection }\end{array}$ & $\begin{array}{l}\text { Major } \\
\text { Bleeding }\end{array}$ & $\begin{array}{l}\text { Exanthema/ } \\
\text { Allergy }\end{array}$ & Edema & $\begin{array}{l}\text { Other } \\
\text { Symptoms }\end{array}$ \\
\hline 1 & - & - & - & exanthema & - & - \\
\hline 2 & - & - & - & - & lid & - \\
\hline 3 & - & - & - & - & - & - \\
\hline 4 & - & - & - & - & lid & - \\
\hline 5 & - & - & - & - & - & - \\
\hline 6 & - & - & - & - & - & diarrhea \\
\hline 7 & - & - & - & exanthema & leg & diarrhea \\
\hline 8 & - & - & - & - & - & - \\
\hline 9 & - & - & - & exanthema & lid & diarrhea \\
\hline 10 & - & - & - & - & - & - \\
\hline 11 & - & - & - & - & - & - \\
\hline 12 & - & - & - & - & leg & - \\
\hline 13 & - & - & - & - & - & - \\
\hline 14 & - & urinary infection & - & - & leg & - \\
\hline 15 & - & - & - & - & - & - \\
\hline 16 & - & - & - & exanthema & - & - \\
\hline 17 & - & bronchitis & - & - & - & - \\
\hline 18 & - & - & - & - & lid & - \\
\hline 19 & - & - & - & - & lid, leg & diarrhea \\
\hline 20 & - & - & - & - & - & diarrhea \\
\hline 21 & - & - & - & - & - & - \\
\hline 22 & - & - & - & - & lid & - \\
\hline 23 & - & - & - & - & - & - \\
\hline
\end{tabular}

Clinical symptoms were examined in a retrospective manner. lid, eyelid.
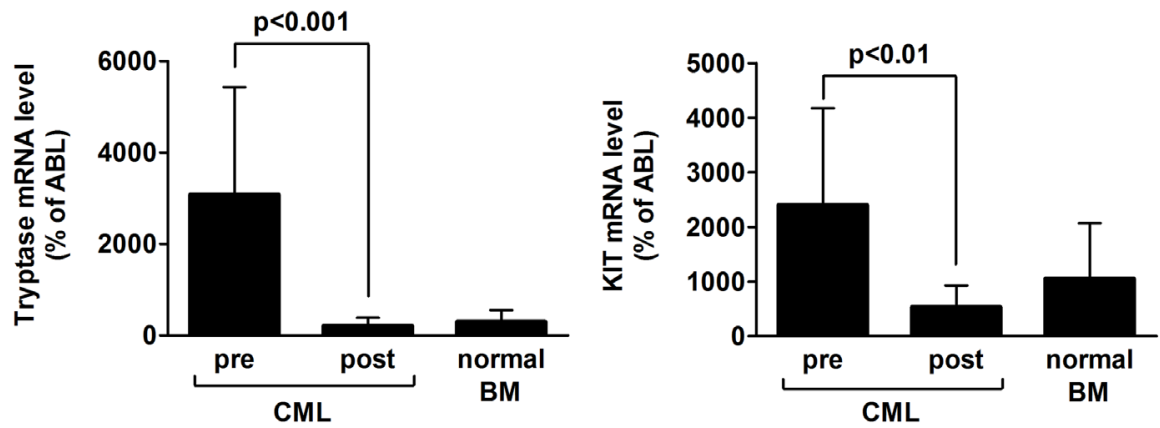

Figure 3: Tryptase mRNA and KIT mRNA levels before and after treatment with imatinib. Isolated bone marrow (BM) cells obtained from $12 \mathrm{CML}$ patients before therapy and after at least 2 years of therapy with imatinib (at the time of major or complete molecular response) were subjected to RNA isolation and qPCR using primers specific for tryptase, KIT, and ABL/EXON1. Results show tryptase mRNA expression levels (left panel) and KIT mRNA expression levels (right panel) as percent of ABL/EXON1 mRNA levels. Results represent the mean \pm S.D. from all donors in each group. Asterisk: ${ }^{*} p<0.05$.

Figure 4: Successful treatment with imatinib induces systemic mast cell deficiency. Total serum tryptase levels were measured in 10 patients with CML at diagnoses and in the same patients after at least 2 years of treatment with imatinib at the time of major or complete molecular response. In addition, serum tryptase levels were measured in 10 healthy controls. Tryptase levels were determined by fluoroenzyme-immunoassay. Results represent the mean \pm S.D. of all donors in each group.

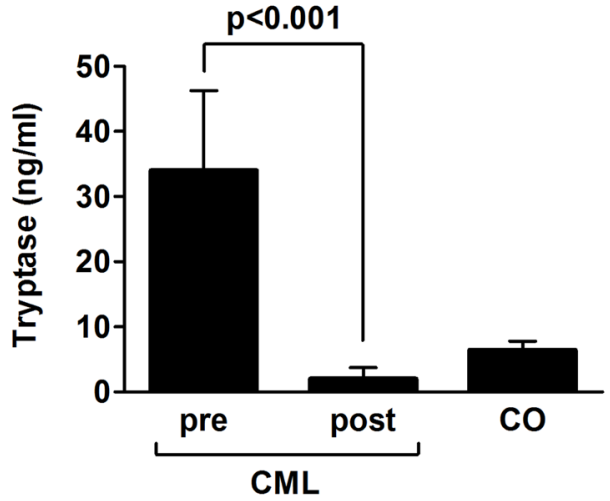


mice (Figure 5). The MC-depleting effect of imatinib was also examined in BALB/c mice. In these experiments, mice were treated with $25 \mathrm{mg} / \mathrm{kg}$ imatinib (i.p. injection) twice daily for 10 days. Treatment of mice with imatinib resulted in a substantial decrease in the percentage of MC and a significant decrease in cellular histamine levels in the peritoneum compared to vehicle control (Figure 5D and $5 \mathrm{E}$ ). Although BALB/c mice were only treated for 10 days, the effect of imatinib was demonstrable until day 31 in all animals (Figure 5D and 5E). Histamine levels on day 31 amounted to $70.33 \pm 5.69 \mathrm{ng} / 10^{6}$ cells in vehicle-controltreated animals, compared to only $2.43 \pm 0.76 \mathrm{ng} / 10^{6}$ cells in imatinib-treated mice $(\mathrm{p}<0.01)$.

\section{DISCUSSION}

Mast cells are key effector cells of the immune system and have been implicated in the pathogenesis of allergic and other immunologic disorders [1-8]. However, whereas the role of $\mathrm{MC}$ in certain disease models is well established, it remains unclear whether MC also play a role as physiologic cells in healthy tissues. This is an important question in basic science as well as in clinical practice because several different drugs are known to block MC function, and some of the recently developed KITblocking TKI may even lead to a decrease in MC numbers. In this study, we show that successful long-term treatment
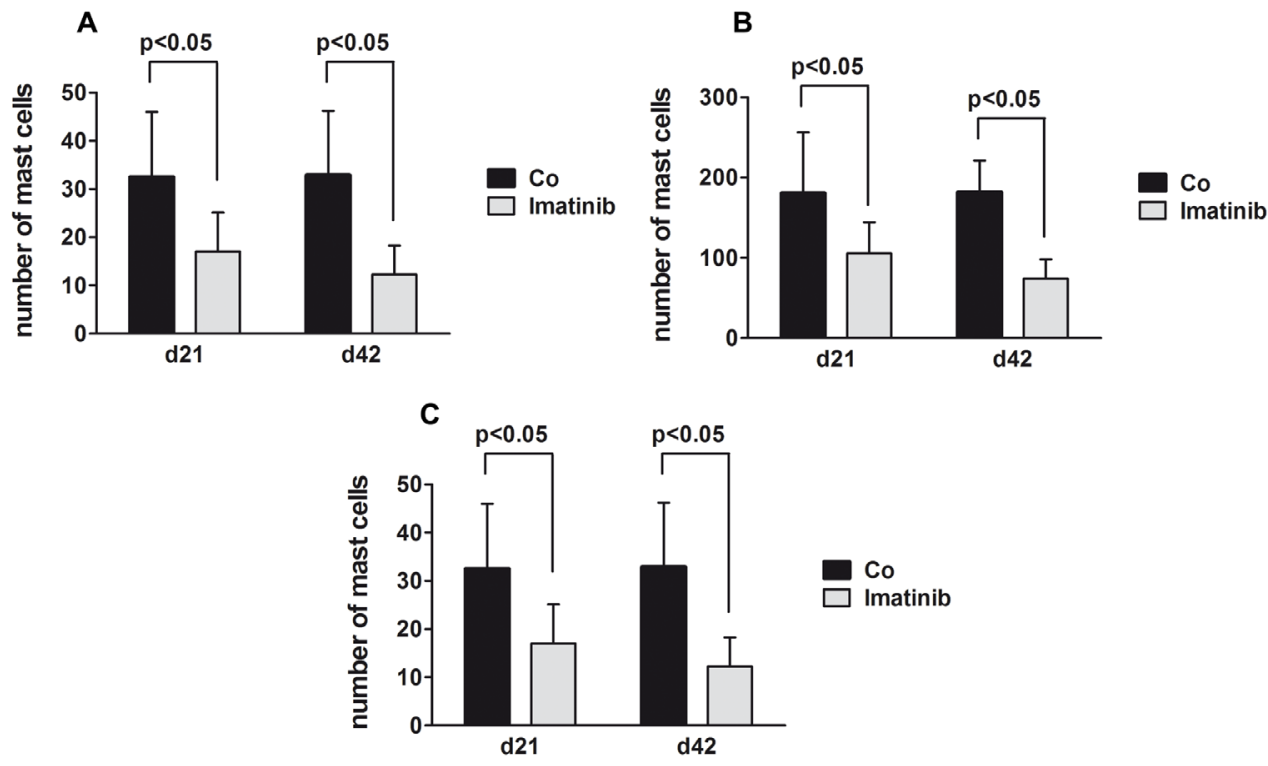

D

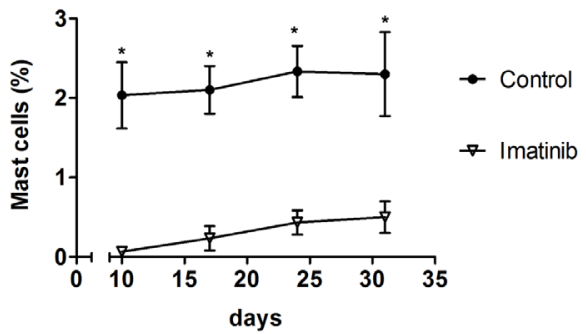

E

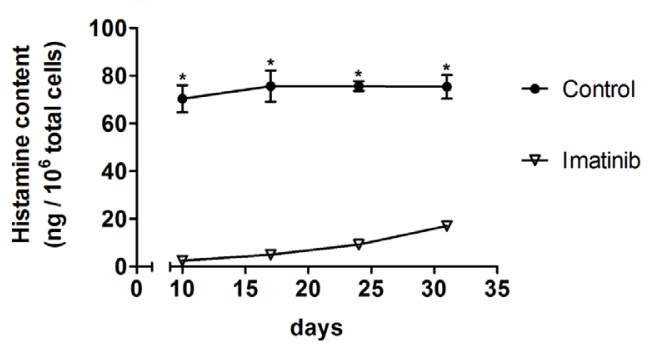

Figure 5: Effects of imatinib on mast cell (MC) numbers in C57BL/6J and BALB/c mice. A-C: C57BL/6J mice were treated with imatinib (60 mg/kg per day) or vehicle control (CO) by intraperitoneal (i.p.) injection for 42 days (5 mice per group). Animals were sacrificed on days 21 or 42 and the percentages of MC in the back skin (A), ear skin (B) and gastric mucosa (C) were determined by staining with toluidine blue (TB) as described in the text. In A, B and C, the numbers of MC was determined by TB staining using a Leica DM 4000 B microscope (Solms, Germany) equipped with a HC Plan Apo 20x/0.70 objective lens. Results are expressed as numbers of TB+ cells per HPF using Discus software (Discus, Columbus, Ohio, USA) and represent the mean \pm S.D. of all mice per group. D-E: Imatinib-induced in vivo depletion of $\mathrm{MC}$ in the peritoneum of $\mathrm{BALB} / \mathrm{c}$ mice. D: Mice were treated with imatinib ( $25 \mathrm{mg} / \mathrm{kg}$ twice daily by i.p. injection) or vehicle alone for 10 days. Peritoneal fluid was recovered in each group of mice $(n=3)$ at various time points (days $10,17,24$ and 31$)$. The percentage of MC among total peritoneal cells was determined in each animal by TB staining using an Olympus BX51 microscope equipped with a UPlanFI 20x/0.50 objective lens. Results are expressed as mean \pm S.D. of all mice in each group (imatinib- or vehicletreated mice). Asterisk: $\mathrm{p}<0.001$. E: Peritoneal fluid samples were adjusted at $10^{6}$ per $\mathrm{mL}$ and subjected to freeze-thawing. Then, cellular histamine levels were determined. Results are expressed as mean concentrations of histamine (ng/10 6 total peritoneal cells) and represent the mean \pm S.D. of all mice per group (imatinib- or vehicle-treated animals). Asterisk: $p<0.001$. 
of CML patients with imatinib results in a profound decrease in $\mathrm{MC}$ numbers. To the best of our knowledge this is the first description of drug-induced depletion of $\mathrm{MC}$ in the human system. In addition, our data show that imatinib inhibits SCF-induced and thus KIT-dependent development of $\mathrm{MC}$ from their $\mathrm{CB}$-derived progenitor cells. However, despite inducing a marked decrease in MC numbers, long-term treatment of CML patients with imatinib was not accompanied by major adverse events or specific symptoms, suggesting that MC may play a less important biological role in steady state homeostasis of healthy tissues than has so far been assumed.

The ligand of KIT, SCF, is a well-known differentiation factor for human MC [1-3,7,26-29]. In the present study, we were able to confirm that SCF induces $\mathrm{MC}$ differentiation in CB-derived progenitor cells [3840]. In these cultures, we applied a combination of SCF and IL- 6 which may be equally potent or even a more potent stimulus of MC differentiation compared to SCF alone [26-29,38-40]. In this assay, imatinib was found to suppress cytokine-induced development of human MC in a dose-dependent manner, with $\mathrm{IC}_{50}$ values of about $10 \mathrm{nM}$ which is a pharmacologically relevant drug concentration. Complete suppression of MC development was seen at $1 \mu \mathrm{M}$ of imatinib. These data suggest that imatinib blocks cytokine-dependent differentiation of MC. Since in vivo development of $\mathrm{MC}$ is also considered to depend primarily on SCF activation of KIT in MC progenitors, this observation may have clinical implications and may explain why $\mathrm{MC}$ decrease in number during treatment with imatinib. However, MC development from their progenitors is a long-lasting process [26-29] and mature MC may persist in local tissue sites for several months to years. Based on observations made in transplanted patients, $\mathrm{MC}$ repopulation from their progenitors may take at least 1 year [31].

Therefore, we decided to examine MC numbers in the BM of our CML patients after 2 years following successful treatment with imatinib in this study. Since MC might also derive from CML stem- and progenitor cells in such patients, a second requirement was that imatinib had produced at least MMR, and that these patients were in MMR or CMR for at least one year. We found that successful long-term treatment with imatinib produces a marked decrease in the numbers of BM MC in these patients. Notably, the numbers of MC decreased from elevated pre-treatment levels to low or even undetectable levels in post-therapy BM samples. The decrease in $\mathrm{MC}$ in BM sections was demonstrable by staining for $\mathrm{MC}$ tryptase and KIT as well as by Giemsa staining. Moreover, we were able to show that imatinib therapy leads to a substantial decrease in tryptase mRNA and KIT mRNA levels in BM cells. It is noteworthy to state that $\mathrm{MC}$ concentrations in the BM not only decreased significantly during imatinib when compared to pre-treatment levels in our CML patients, but also when compared to MC numbers recorded in the BM of normal healthy controls. Collectively, these data suggest that long-term treatment with imatinib not only resulted in a markedly suppressed developent of normal MC but also in suppression of growth of clonal $(\mathrm{BCR} / \mathrm{ABL}+) \mathrm{MC}$ progenitors, which was confirmed by qPCR.

To demonstrate that the decrease in MC numbers in the $\mathrm{BM}$ is a long-lasting process and time-dependent, we also examined a smaller cohort of patients after one year of treatment with imatinib. In these patients, no significant decrease in $\mathrm{MC}$ numbers was found when compared to pre-treatment values. We also examined other cell types in the BM and in the peripheral blood. However, we were not able to detect a significant decrease of any other cell type, including basophils, eosinophils or monocytes in our imatinib-treated CML patients, regardless of the time point examined. This observation is consistent with the notion that MC development is specifically dependent on KIT and thus SCF, whereas the development of other hematopoietic cell types is dependent on other cytokines, but not SCF [1-7,26-29]. These data also support the concept that MC are not derived from blood monocytes or blood basophils as evidenced by our previous studies [41].

$\mathrm{MC}$ are well-known to reside in various tissues and organ systems [1-8]. Therefore, we were interested to learn whether imatinib induces local MC deficiency in the BM or a systemic or even global MC deficiency. Since we were unable to examine all organ systems by biopsy in our CML patients, we decided to measure serum total tryptase levels before and after (during) successful therapy with imatinib. In this regard it is noteworthy to state that the basal tryptase level usually results from a constant release of the enzyme from MC in various tissues $[42,43]$. Therefore, the basal tryptase level is a generally accepted parameter of the total body burden of MC in healthy controls. During anaphylaxis, serum tryptase levels may transiently increase, and in patients with systemic mastocytosis, serum tryptase levels are persistently elevated $[43,44]$. We were interested to learn whether imatinib would directly block the spontaneous or IgEdependent release of tryptase from human MC. However, imatinib failed to block spontaneous or anti-IgE-induced release of histamine or tryptase in human MC.

In patients with CML, elevated serum tryptase levels were detected at diagnosis in a subset of patients, confirming our previous data $[45,46]$. However, in contrast to mastocytosis, elevated tryptase levels in CML apparently result from an increased production and release in immature basophils $[45,46]$. Successful longterm treatment of our CML patients with imatinib was found to result in a significant decrease in serum tryptase levels. These tryptase levels were found to be even lower compared to that found in healthy controls. Collectively, these data suggest that long-term therapy with imatinib produces not only a substantial decrease in clonal tryptase+ cells (MC and immature basophils) in the BM but also a 
markedly reduced systemic production of normal MC in various organ systems. An alternative explanation would be that imatinib inhibits the basal secretion of tryptase from MC. However, this possibility could be eliminated as outlined above. Another explanation would be that a selective depletion of $\mathrm{MC}$ in the $\mathrm{BM}$ is sufficient to decrease serum tryptase levels. However, this possibility seems unlikely. In fact, the numbers of MC in the lungs, skin, and in the gastrointestinal tract exceed $\mathrm{MC}$ numbers in the BM by far, so that a selective decrease in BM MC should not lead to a visible decrease in tryptase levels.

To provide definitive evidence for a systemic effect of imatinib on MC development, we employed two different mouse strains, namely C57BL/6J and BABL/c. In both models, animals were treated with imatinib by i.p. injection, and in both types of mice, the drug produced a substantial decrease in MC numbers in all organs tested, including the skin, peritoneum and the gastric mucosa. In contrast to the human system, imatinib-induced MC depletion in mice was already seen after a few weeks, which may be explained by the fact that the development of murine MC occurs within a (much) shorter time interval compared to SCF-dependent development of human MC.

$\mathrm{MC}$ are well known to fulfil important functions in the immune system and in allergic reactions [1-9]. Moreover, MC have been described to play a potential role as repair cells during infections and during or/and after a thromboembolic event [16-23]. Therefore, we were interested to learn whether imatinib-induced MC deficiency would predispose for certain adverse events, such as thromboembolic events, bacterial or fungal infections or cancer development. However, although investigated thoroughly, we were unable to detect an increased frequency of bacterial or fungal infections, cancer, or thromboembolic events in our imatinib-treated patients with CML.

In conclusion, our study shows that the KITblocking TKI imatinib produces a profound decrease in $\mathrm{MC}$ in mice as well as a decrease in $\mathrm{MC}$ in patients with $\mathrm{Ph}+\mathrm{CML}$. However, imatinib-induced MC depletion is not accompanied by specific adverse events or symptoms, suggesting that $\mathrm{MC}$ are less important cells in the homeostasis of normal healthy tissues than has been assumed so far. Finally, imatinib-induced MC depletion is lineage-specific and not accompanied by a substantial decrease in other leukocytes, confirming that MC are derived from a separate stem cell pool but not from mature blood basophils or blood monocytes.

\section{PATIENTS AND METHODS}

\section{Patients' characteristics and bone marrow sampling}

Bone marrow biopsy specimens were obtained from 29 patients with $\mathrm{Ph}+\mathrm{CML}$. Diagnoses were established according to WHO criteria [47]. The patients' characteristics are shown in Table 1. Informed consent was obtained in all patients before BM or blood was obtained. All studies were approved by the ethics committee of the Medical University of Vienna. In 23 patients, biopsy material was obtained at diagnosis and at the time of major (MMR) or complete (CMR) molecular response and at least two years of therapy with imatinib (400 mg/ day). In a smaller cohort of patients $(n=6), B M$ samples were examined at diagnosis and within the first year of treatment. All patients were examined for the development of adverse events during treatment with imatinib. Furthermore, we examined normal/reactive bone marrow $(n=5)$ as control.

\section{Reagents}

The monoclonal antibody (mAb) G3 (IgG1) against tryptase was purchased from Chemicon (Temecula, CA), a rabbit polyclonal antibody against KIT (CD117) from Dako (Glostrup, Denmark), biotinylated anti-rabbit IgG, anti-mouse IgG and Vectastain Universal ABC-AP Kit from Vector Laboratories (Burlingham, CA), and 3-amino9-ethylcarbazole (AEC) from Sigma (St.Louis, MO, USA). Imatinib was kindly provided by Dr.E.Buchdunger and Dr.P.Manley (Novartis Pharma AG, Basel, Switzerland). Recombinant human (rh) stem cell factor (SCF) was from Strathmann Biotech (Hannover, Germany) and rh interleukin-6 (IL-6) from Novartis Pharma AG. RPMI 1640 medium and fetal calf serum (FCS) were purchased from PAA laboratories (Pasching, Austria) and a histamine radioimmuno-assay (RIA) from Immunotech (Marseilles, France). Serum and cellular tryptase levels were measured by fluoroenzyme-immunoassay (FEIA, Thermo Fisher Scientific, Uppsala, Sweden). The detection limit for total (alpha+beta-type) tryptase in this assay was $1 \mathrm{ng} / \mathrm{mL}$. The median serum tryptase level in healthy controls amounts to $5.6 \pm 2.8 \mathrm{ng} / \mathrm{mL}$ (range: $0-15 \mathrm{ng} / \mathrm{mL}$ ) [48].

\section{Mast cell differentiation assay}

Ficoll-isolated cord blood (CB) mononuclear cells $\left(\mathrm{MNC}, 1 \times 10^{6} / \mathrm{ml}\right)$ were cultured in 24-well plates in RPMI 1640 medium containing 10\% FCS, SCF (100 $\mathrm{ng} / \mathrm{ml})$ and IL-6 (100 ng/ml). Cultures were maintained with or without various concentrations of imatinib (0.001- 
$1 \mu \mathrm{M})$. After 2 weeks, medium, cytokines and imatinib were replaced. After 4 weeks, cells were recovered and examined for the percentage of MC by Wright-Giemsastaining, for their histamine- and tryptase content (after freeze-thawing), and for expression of tryptase- and KIT mRNA levels by qPCR. Histamine concentrations were determined by RIA and total tryptase concentrations by FEIA.

\section{Immunohistochemical staining of $\mathrm{BM}$ sections}

The indirect immunoperoxidase staining technique was performed with serial sections $(2 \mu \mathrm{M})$ of formalinfixed and paraffin-embedded BM as described [49-51]. For $\mathrm{MC}$ detection and enumeration, antibodies against KIT (CD117) (polyclonal) and tryptase (mAb G3) were applied overnight. Slides were then washed and incubated with biotinylated anti-rabbit IgG or anti-mouse IgG, washed, and then exposed to streptavidin-biotin-peroxidasecomplex. AEC was used as chromogen. The numbers of tryptase + cells and KIT + cells $(\mathrm{MC})$ were determined using an Olympus BX50F4 microscope connected to a DP21 camera (Olympus, Hamburg, Germany) and expressed as percent of nucleated BM cells. We also confirmed the presence of MC by Giemsa staining and counted the numbers of MC on Giemsa-stained BM sections in our CML patients.

\section{Quantitative PCR (qPCR)}

KIT- and tryptase mRNA levels were quantified in patient-derived BM MNC and cultured CB MNC-derived MC by qPCR essentially as described [52]. PCR primers used in this study are shown in Supplementary Table S1. Expression of KIT- and tryptase mRNA was quantified on a 7900HT Fast Real-Time PCR System (Applied Biosystems, Foster City, CA) using iTaq SYBR Green Supermix with ROX from Bio-Rad (Hercules, CA). KIT mRNA levels and tryptase mRNA levels were expressed as percent of ABL. In clinical follow-up samples, BCR/ ABL1 mRNA levels were adjusted according to the international scale (IS) [53]. Conventional karyotyping and fluorescence in situ-hybridization (FISH) were performed according to published protocols [54].

\section{Treatment of C57BL/6J mice and BALB/c mice with imatinib}

Two different mouse strains were examined, C57BL/6J mice obtained from the central animal facility of the University of Cologne (Cologne, Germany) and $\mathrm{BALB} / \mathrm{c}$ mice purchased from IFFA-CREDO (SaintGermain Sur L'arbresle, France). All animal experiments were approved by the local ethics committees for animal research of the University of Cologne and the Ecole Normale Supérieure de Cachan (Cachan, France). Both groups of mice were treated with imatinib by intraperitoneal (i.p.) injection. C57BL/6J mice (8-12 week-old) were treated with imatinib $(60 \mathrm{mg} / \mathrm{kg}$ per day) or vehicle control (10 mice per group) for 42 days. After 21 days and 42 days, animals (10 each time point) were sacrificed. In each group of animals, the skin (back skin and ear skin), gastric submucosa, and splenic tissues were fixed in formalin and embedded in paraffin. Tissue sections were then examined for the presence and percentage of MC by Toludine Blue (TB) staining. The percentage of $\mathrm{TB}+$ cells $(\mathrm{MC})$ among all nucleated cells was determined by counting cells in five different high power fields (HPF). In a separate set of experiments, twenty-four 6 week-old BALB/c mice were divided into two groups of 12 mice each. One group received $25 \mathrm{mg} /$ $\mathrm{kg}$ imatinib (dissolved in $0.5 \mathrm{~mL}$ PBS) twice daily by i.p. injection for 10 consecutive days, and the second (control) group of mice received vehicel control. On days 10, 17, 24 , and 31 , each 3 mice were sacrificed and peritoneal cells collected after i.p. injection of pre-warmed $\left(37^{\circ} \mathrm{C}\right)$ phenol-red-free RPMI 1640 medium (Gibco Laboratories, Grand Island, NY). Peritoneal cell suspensions were examined for the percentage of $\mathrm{MC}$ by $\mathrm{TB}$ staining (on a hematocytometer) and for the levels of histamine. For determining histamine levels, $10^{6}$ peritoneal cells were centrifuged and resuspended in $1 \mathrm{ml}$ of phenol red-free RPMI 1640 medium. Cell suspensions were then subjected to freeze-thawing, and histamine concentrations were determined by an automated flow-fluorometric technique as described [55]. Total histamine content in peritoneal cell suspensions was expressed in ng per $10^{6}$ cells.

\section{Statistical analysis}

Significance levels were calculated by standard tests, including the Student's t-test and analysis of variance (ANOVA). Differences were considered significant when $\mathrm{p}<0.05$.

\section{ACKNOWLEDGMENTS}

The study was supported by the Austrian National Science Funds, SFB grant F4704-B20.

\section{Authorship}

S.C.R. contributed immunocytochemical and immunohistochemistry experiments, PCR, functional bioassays, and wrote parts of the manuscript. A.R. contributed mouse experiments, bioassays and performed statistical analysis. G.S. contributed qPCR and immunoassay experiments. S.H. collected patients' data and provided logistic support. G.H. contributed 
immunoassays, bioassays and performed statistical analysis. L.M. contributed tissue sections and staining experiments. S.B. provided cord blood cell cultures. C.B.S. contributed tissue sections, collected samples and patients' data. W.R.S. contributed patients, collected patients' samples and data, and provided statistics. C.M. contributed molecular studies and provided logistic support. H.S. and W.L. contributed patients and collected samples as well as patients' data. M.A. contributed mouse experiments (BALB/c) and bioassays and provided logistic support. K.H. contributed mouse experiments (C57/B6J) and performed statistical analysis. P.V. contributed the study design, established the work plan, provided logistics, and wrote the paper. All authors approved the final version of the manuscript.

\section{Conflict of interest disclosures}

P.V. received research funding and honoraria from Novartis. The remaining authors declare that they have no competing financial interests or other conflict of interest to disclose in this study.

\section{REFERENCES}

1. Galli SJ. New insights into "the riddle of the mast cells": microenvironmental regulation of mast cell development and phenotypic heterogeneity. Lab Invest. 1990; 62:5-33.

2. Valent P, Bettelheim P. Cell surface structures on human basophils and mast cells: biochemical and functional characterization. Adv Immunol. 1992; 52:333-423.

3. Galli SJ. New concepts about the mast cell. N Engl J Med. 1993; 328:257-265.

4. Taylor ML, Metcalfe DD. Mast cells in allergy and host defense. Allergy Asthma Proc. 2001; 22:115-119.

5. Gurish MF, Austen KF. The diverse roles of mast cells. J Exp Med. 2001; 194:1-5.

6. Galli SJ, Kalesnikoff J, Grimbaldeston MA, Piliponsky AM, Williams CM, Tsai M. Mast cells as "tunable" effector and immunoregulatory cells: recent advances. Annu Rev Immunol. 2005; 23:749-786.

7. Metcalfe DD. Mast cells and mastocytosis. Blood. 2008; 112:946-956.

8. Galli SJ, Tsai M. Mast cells: versatile regulators of inflammation, tissue remodeling, host defense and homeostasis. J Dermatol Sci. 2008; 49:7-19.

9. Kinet JP, Blank U, Brini A, Jouvin MH, Küster H, Mejan $\mathrm{O}, \mathrm{Ra} \mathrm{C}$. The high-affinity receptor for immunoglobulin $\mathrm{E}$ : a target for therapy of allergic diseases. Int Arch Allergy Appl Immunol. 1991; 94:51-55.

10. Siraganian RP. Mast cell signal transduction from the highaffinity IgE receptor. Curr Opin Immunol. 2003; 15:639646.

11. Wodnar-Filipowicz A, Heusser CH, Moroni C. Production of the haemopoietic growth factors GM-CSF and interleukin-3 by mast cells in response to IgE receptormediated activation. Nature. 1989; 339:150-152.

12. Plaut M, Pierce JH, Watson CJ, Hanley-Hyde J, Nordan RP, Paul WE. Mast cell lines produce lymphokines in response to cross-linkage of Fc epsilon RI or to calcium ionophores. Nature. 1989; 339:64-67.

13. Galli SJ, Wershil BK, Gordon JR, Martin TR. Mast cells: immunologically specific effectors and potential sources of multiple cytokines during IgE-dependent responses. Ciba Found Symp. 1989; 147:53-65.

14. Gordon JR, Galli SJ. Mast cells as a source of both preformed and immunologically inducible TNF-alpha/ cachectin. Nature. 1990; 346:274-276.

15. Dvorak AM. Subcellular localization of the cytokines, basic fibroblast growth factor and tumor necrosis factor-alpha in mast cells. Chem Immunol Allergy. 2005; 85:72-88.

16. Sillaber C, Baghestanian M, Bevec D, Willheim M, Agis H, Kapiotis S, Füreder W, Bankl HC, Kiener HP, Speiser W, Binder BR, Lechner K, Valent P. The mast cell as site of tissue-type plasminogen activator expression and fibrinolysis. J Immunol. 1999; 162:1032-1041.

17. Sillaber C, Baghestanian M, Hofbauer R, Virgolini I, Bankl HC, Füreder W, Agis H, Willheim M, Leimer M, Scheiner $\mathrm{O}$, Binder BR, Kiener HP, et al. Molecular and functional characterization of the urokinase receptor on human mast cells. J Biol Chem. 1997; 272:7824-7832.

18. Valent P, Baghestanian M, Bankl HC, Sillaber C, Sperr WR, Wojta J, Binder BR, Lechner K. New aspects in thrombosis research: possible role of mast cells as profibrinolytic and antithrombotic cells. Thromb Haemost. 2002; 87:786-790.

19. Bankl HC, Radaszkiewicz T, Klappacher GW, Glogar D, Sperr WR, Grossschmidt K, Bankl H, Lechner K, Valent P. Increase and redistribution of cardiac mast cells in auricular thrombosis. Possible role of kit ligand. Circulation. 1995; 91:275-283.

20. Bankl HC, Grossschmidt K, Pikula B, Bankl H, Lechner K, Valent $\mathrm{P}$. Mast cells are augmented in deep vein thrombosis and express a profibrinolytic phenotype. Hum Pathol. 1999; 30:188-194.

21. Kitamura $Y$, Taguchi $T$, Yokoyama $M$, Inoue $M$, Yamatodani A, Asano H, Koyama T, Kanamaru A, Hatanaka K, Wershil BK, Galli SJ. Higher susceptibility of mast-cell-deficient $\mathrm{W} / \mathrm{WV}$ mutant mice to brain thromboembolism and mortality caused by intravenous injection of India ink. Am J Pathol. 1986; 122:469-480.

22. Echtenacher B, Männel DN, Hültner L. Critical protective role of mast cells in a model of acute septic peritonitis. Nature 1996; 381:75-77.

23. Malaviya R, Ikeda T, Ross E, Abraham SN. Mast cell modulation of neutrophil influx and bacterial clearance at sites of infection through TNF-alpha. Nature. 1996; 381 :7780.

24. Kitamura Y, Go S, Hatanaka K. Decrease of mast cells 
in $\mathrm{W} / \mathrm{Wv}$ mice and their increase by bone marrow transplantation. Blood. 1978; 52:447-452.

25. Kitamura Y, Go S. Decreased production of mast cells in S1/S1d anemic mice. Blood. 1979; 53:492-497.

26. Valent P, Spanblöchl E, Sperr WR, Sillaber C, Zsebo KM, Agis H, Strobl H, Geissler K, Bettelheim P, Lechner $\mathrm{K}$. Induction of differentiation of human mast cells from bone marrow and peripheral blood mononuclear cells by recombinant human stem cell factor/kit-ligand in long-term culture. Blood. 1992; 80:2237-2245.

27. Kirshenbaum AS, Goff JP, Kessler SW, Mican JM, Zsebo KM, Metcalfe DD. Effect of IL-3 and stem cell factor on the appearance of human basophils and mast cells from CD34+ pluripotent progenitor cells. J Immunol. 1992; 148:772-777.

28. Valent $P$. The riddle of the mast cell: kit(CD117)-ligand as the missing link? Immunol Today. 1994; 15:111-114.

29. Galli SJ, Tsai M, Wershil BK. The c-kit receptor, stem cell factor, and mast cells. What each is teaching us about the others. Am J Pathol. 1993; 142:965-974.

30. Sillaber C, Strobl H, Bevec D, Ashman LK, Butterfield JH, Lechner K, Maurer D, Bettelheim P, Valent P. IL-4 regulates c-kit proto-oncogene product expression in human mast and myeloid progenitor cells. J Immunol. 1991; 147:4224-4228.

31. Födinger $M$, Fritsch $G$, Winkler $K$, Emminger $W$, Mitterbauer G, Gadner H, Valent P, Mannhalter C. Origin of human mast cells: development from transplanted hematopoietic stem cells after allogeneic bone marrow transplantation. Blood. 1994; 84:2954-2959.

32. O'Brien SG, Guilhot F, Larson RA, Gathmann I, Baccarani M, Cervantes F, Cornelissen JJ, Fischer T, Hochhaus A, Hughes T, Lechner K, Nielsen JL, Rousselot P, et al. Imatinib compared with interferon and low-dose cytarabine for newly diagnosed chronic-phase chronic myeloid leukemia. N Engl J Med. 2003; 348:994-1004.

33. Druker BJ, Guilhot F, O'Brien SG, Gathmann I, Kantarjian H, Gattermann N, Deininger MW, Silver RT, Goldman JM, Stone RM, Cervantes F, Hochhaus A, Powell BL, et al. Five-year follow-up of patients receiving imatinib for chronic myeloid leukemia. N Engl J Med. 2006; 355:24082417.

34. Deininger M, Buchdunger E, Druker BJ. The development of imatinib as a therapeutic agent for chronic myeloid leukemia. Blood. 2005; 105:2640-2653.

35. Druker BJ. Translation of the Philadelphia chromosome into therapy for CML. Blood. 2008; 112:4808-4817.

36. Gotlib J, Cools J, Malone JM 3rd, Schrier SL, Gilliland DG, Coutré SE. The FIP1L1-PDGFRalpha fusion tyrosine kinase in hypereosinophilic syndrome and chronic eosinophilic leukemia: implications for diagnosis, classification, and management. Blood. 2004; 103:2879-2891.

37. Manley PW, Cowan-Jacob SW, Buchdunger E, Fabbro D, Fendrich G, Furet P, Meyer T, Zimmermann J. Imatinib: a selective tyrosine kinase inhibitor. Eur J Cancer. 2002;
38:19-27.

38. Yanagida M, Fukamachi H, Ohgami K, Kuwaki T, Ishii H, Uzumaki H, Amano K, Tokiwa T, Mitsui H, Saito H, Iikura Y, Ishizaka T, Nakahata T. Effects of T-helper 2-type cytokines, interleukin-3 (IL-3), IL-4, IL-5, and IL-6 on the survival of cultured human mast cells. Blood. 1995; 86:3705-3714.

39. Saito H, Ebisawa M, Sakaguchi N, Onda T, Iikura Y, Yanagida M, Uzumaki H, Nakahata T. Characterization of cord-blood-derived human mast cells cultured in the presence of Steel factor and interleukin-6. Int Arch Allergy Immunol. 1995; 107:63-65

40. Saito H, Ebisawa M, Tachimoto H, Shichijo M, Fukagawa K, Matsumoto K, Iikura Y, Awaji T, Tsujimoto G, Yanagida M, Uzumaki H, Takahashi G, Tsuji K, et al. Selective growth of human mast cells induced by Steel factor, IL-6, and prostaglandin E2 from cord blood mononuclear cells. J Immunol. 1996; 157:343-350.

41. Agis H, Willheim M, Sperr WR, Wilfing A, Krömer E, Kabrna E, Spanblöchl E, Strobl H, Geissler K, Spittler A, Boltz-Nitulescu G, Majdic O, Lechner K, et al. Monocytes do not make mast cells when cultured in the presence of SCF. Characterization of the circulating mast cell progenitor as a c-kit+, CD34+, Ly-, CD14-, CD17-, colony-forming cell. J Immunol. 1993; 151:4221-4227.

42. Schwartz LB, Sakai K, Bradford TR, Ren S, Zweiman B, Worobec AS, Metcalfe DD. The alpha form of human tryptase is the predominant type present in blood at baseline in normal subjects and is elevated in those with systemic mastocytosis. J Clin Invest. 1995; 96:2702-2710.

43. Kanthawatana S, Carias K, Arnaout R, Hu J, Irani AM, Schwartz LB. The potential clinical utility of serum alpha-protryptase levels. J Allergy Clin Immunol. 1999; 103:1092-1099.

44. Sperr WR, Jordan JH, Fiegl M, Escribano L, Bellas C, Dirnhofer S, Semper H, Simonitsch-Klupp I, Horny HP, Valent P. Serum tryptase levels in patients with mastocytosis: correlation with mast cell burden and implication for defining the category of disease. Int Arch Allergy Immunol. 2002; 128:136-141.

45. Samorapoompichit P, Kiener HP, Schernthaner GH, Jordan JH, Agis H, Wimazal F, Baghestanian M, Rezaie-Majd A, Sperr WR, Lechner K, Valent P. Detection of tryptase in cytoplasmic granules of basophils in patients with chronic myeloid leukemia and other myeloid neoplasms. Blood. 2001; 98:2580-2583.

46. Sperr WR, El-Samahi A, Kundi M, Girschikofsky M, Winkler S, Lutz D, Endler G, Rumpold H, Agis H, Sillaber C, Jäger U, Valent P. Elevated tryptase levels selectively cluster in myeloid neoplasms: a novel diagnostic approach and screen marker in clinical haematology. Eur J Clin Invest. 2009; 39:914-923.

47. Vardiman JW, Harris NL, Brunning RD. The World Health Organization (WHO) classification of the myeloid neoplasms. Blood. 2002; 100:2292-2302. 
48. Valent P, Sperr WR, Sotlar K, Reiter A, Akin C, Gotlib J, Horny HP, Arock M. The serum tryptase test: an emerging robust biomarker in clinical hematology. Expert Rev Hematol. 2014; 7:683-690.

49. Cattoretti G, Pileri S, Parravicini C, Becker MH, Poggi S, Bifulco C, Key G, D’Amato L, Sabattini E, Feudale E, et al. Antigen unmasking on formalin-fixed, paraffin-embedded tissue sections. J Pathol. 1993; 171:83-98.

50. Jordan JH, Walchshofer S, Jurecka W, Mosberger I, Sperr WR, Wolff K, Chott A, Bühring HJ, Lechner K, Horny HP, Valent P. Immunohistochemical properties of bone marrow mast cells in systemic mastocytosis: evidence for expression of CD2, CD117/Kit, and bcl-x(L). Hum Pathol. 2001; 32:545-552.

51. Baumgartner C, Cerny-Reiterer S, Sonneck K, Mayerhofer M, Gleixner KV, Fritz R, Kerenyi M, Boudot C, Gouilleux F, Kornfeld JW, Sillaber C, Moriggl R, Valent P. Expression of activated STAT5 in neoplastic mast cells in systemic mastocytosis: subcellular distribution and role of the transforming oncoprotein KIT D816V. Am J Pathol. 2009; 175:2416-2429.

52. Cerny-Reiterer S, Ghanim V, Hoermann G, Aichberger KJ, Herrmann H, Muellauer L, Repa A, Sillaber C, Walls AF, Mayerhofer M, Valent P. Identification of basophils as a major source of hepatocyte growth factor in chronic myeloid leukemia: a novel mechanism of BCR-ABL1independent disease progression. Neoplasia. 2012; 14:572584.

53. Hughes T, Deininger M, Hochhaus A, Branford S, Radich J, Kaeda J, Baccarani M, Cortes J, Cross NC, Druker BJ, Gabert J, Grimwade D, Hehlmann R, et al. Monitoring CML patients responding to treatment with tyrosine kinase inhibitors: review and recommendations for harmonizing current methodology for detecting BCR-ABL transcripts and kinase domain mutations and for expressing results. Blood. 2006; 108: 28-37.

54. Brothman AR, Persons DL, Shaffer LG. Nomenclature evolution: Changes in the ISCN from the 2005 to the 2009 edition. Cytogenet Genome Res. 2009; 127:1-4.

55. Level B. A high sampling rate automated continuous flow fluorometric technique for the analysis of nanogram (ng) levels of histamine in biological samples. Anal Biochem. 1983; 133:16-29. 